\title{
The Resistance and Strength of Soft Solder Splices between Conductors in MICE Coils
}

\author{
H. Wu, H. Pan, M. A. Green Member IEEE, D. Dietderich Member IEEE, T. E. Gartner, \\ H. C. Higley, M. Mentink, D. G. Tam, F. Y. Xu, F. Trillaud, X. K. Liu, L. Wang, and S. X. Zheng
}

\begin{abstract}
Two of the three types of MICE magnets will have splices within their coils. The MICE coupling coils may have as many as fifteen one-meter long splices within them. Each of the MICE focusing coils may have a couple of 0.25 -meter long conductor splices. Equations for the calculation of resistance of soldered lap splices of various types are presented. This paper presents resistance measurements of soldered lap splices of various lengths. Measured splice resistance is shown for one-meter long splices as a function of the fabrication method. Another important consideration is the strength of the splices. The measured breaking stress of splices of various lengths is presented in this paper. Tin-lead solders and tin-silver solders were used for the splices that were tested. From the data given in this report, the authors recommend that the use of lead free solders be avoided for low temperature coils.
\end{abstract}

Index Terms-Conductor Splice Resistance and Strength.

\section{INTRODUCTION}

$\mathrm{S}$ plices are common occurrence in superconducting $\checkmark$ magnets of all types [1]. Splices fall into two general categories superconducting splices and normal splices. Magnets that must run in persistent mode generally have splices that are superconducting. Normal splices involve connecting the normal stabilizer metal of one conductor with the normal metal of the second conductor. In a normal splice the current flow from the superconductor of the first conductor through normal metal to the superconductor of the second conductor. This paper discusses normal splices between conductors that can be wound into a superconducting coil.

The magnets for the muon ionization cooling experiment (MICE) [2] cooling channel are a case in point. Two types of these coils contain splices because the available conductor piece lengths are too short. Because the coil currents are low $(<300 \mathrm{~A})$ and the splices are not cooled with helium directly, the splice resistance must also be low $(<10 \mathrm{n} \Omega)$. MICE coil splices must have the following characteristics; 1) the splice must be less than one turn length, 2) the longitudinal or radial space occupied by an insulated splice must be less than the space occupied by two turns within the coil.

Manuscript received 3 August 2010. This work was supported by funds of the cryogenic and superconductivity technology innovation project under the "985-2" plan of Harbin Institute of Technology. This work was also supported by the Office of Science, United States Department of Energy under contract DE-AC-02-05CH11231.

H. Wu, H. Pan, F. Y. Xu, X. K. Liu, and S. X. Zheng are with the Institute of Cryogenics and Superconductive Technology, HIT, Harbin 150001, China. L. Wang, is with the Shanghai Institute of Applied Physics, Shanghai 201204, China. M. A. Green is with Lawrence Berkeley National Laboratory, Berkeley CA, 94720 USA (e-mail: magreen@1bl.gov). D. Diederich, T. Gartner, H. Higley, M. Mentik D. Tam, and F. Trillaud are also with LBNL.

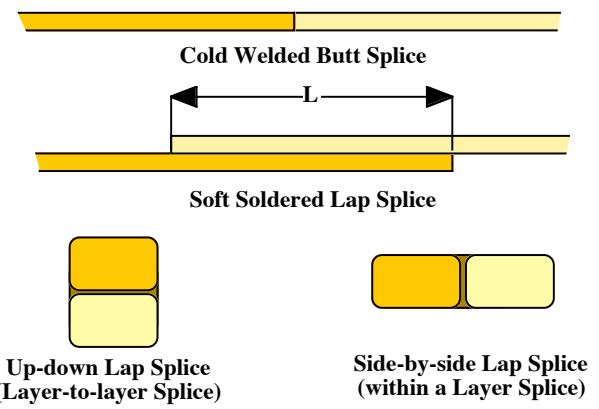

Fig. 1. Cold Welded Butt Splice and Two Types of Lap Splices

Fig. 1 shows the three types of normal splices were studied; cold welded butt splices, soldered up-down lap splices, and soldered side-by-side lap splices [3], [4]. The fabricators for the coupling magnet [5] and the AFC magnet [6] have chosen to make their splices at the ends of a layer, so that the splice is a transition from one layer to the next. Therefore, the measurements presented here are for up-down soldered lap splices, which can be used at the ends of a coil layer.

\section{Calculation of Splice Parameters}

\section{A. Calculation of the Splice Resistance}

The resistance for a butt splice can be expressed as follows;

$$
R_{j}=\frac{\rho_{j} L_{J}}{A_{c j}} \frac{(r+1)}{r}
$$

where $R_{j}$ is the resistance of the splice; $\rho_{j}$ is the electrical resistivity of the weld material in the splice; $L_{j}$ is the length of the fused region within the splice; $r$ is the copper to superconductor ratio for the conductor; and $A_{c j}$ is the cross-sectional area of the conductor. For a MICE conductor butt splice, $\rho_{\mathrm{J}}=1.6 \times 10^{-9} \Omega \mathrm{m}, \mathrm{L}_{\mathrm{j}}=100 \mu \mathrm{m}$, and $\mathrm{A}_{\mathrm{cj}}=1.5 \times 10^{-6}$ $\mathrm{m}^{2}$. The calculated resistance of this splice is $106 \mathrm{n} \Omega$, which is too high for MICE magnets [7].

The calculated resistance of a lap splice is divided into two terms, the copper resistance and the solder resistance. The un-insulated MICE coupling coil conductor has a width $\mathrm{w}=$ $1.6 \mathrm{~mm}$ and a thickness $\mathrm{t}=0.95 \mathrm{~mm}$. The coupling coil conductor has rounded corner $\mathrm{R}_{\mathrm{c}}=0.2 \mathrm{~mm}$. The resistance of up-down lap splices is given by the following expression;

$$
R_{j}=\frac{2 \rho_{C u} t_{C u}}{L\left(w-2 R_{c}\right)}+\frac{\rho_{s o l} t_{s o l}}{L\left(w-2 R_{c}\right)}
$$


The resistance for side-by-side lap splices is as follows;

$$
R_{j}=\frac{2 \rho_{C u} t_{C u}}{L\left(t-2 R_{c}\right)}+\frac{\rho_{s o l} t_{s o l}}{L\left(t-2 R_{c}\right)}
$$

where $\mathrm{L}$ is the length of the lap splice (See Fig. 1); $\rho_{\mathrm{Cu}}$ is the resistivity of the conductor copper; $\rho_{\text {sol }}$ is the resistivity of the conductor copper; $t_{\mathrm{Cu}}$ is the thickness of the conductor copper; and $t_{\text {sol }}$ is the thickness of the conductor copper. In the coupling magnet the average field at a splice is about $5 \mathrm{~T}$. At this induction, $\rho_{\mathrm{Cu}}=4.63 \times 10^{-10} \Omega \mathrm{m}(\mathrm{RRR}=70 \mathrm{Cu})[8]$ and $\rho_{\text {sol }}=5.74 \times 10^{-9} \Omega \mathrm{m}$ (tin-lead eutectic solder) [9]. A coupling coil splice may have $\mathrm{L}=1 \mathrm{~m}, \mathrm{t}_{\mathrm{Cu}}=150 \mu \mathrm{m}$, and $\mathrm{t}_{\mathrm{sol}}=100 \mu \mathrm{m}$. For an up-down splice the calculated resistance is $0.58 \mathrm{n} \Omega$. For a side-by side splice the calculated resistance is $1.37 \mathrm{n} \Omega$. (At $0 \mathrm{~T}$, the splice resistance is about 15 percent lower.)

The equations above assume that there is no solder in the space between the corners. Without rounded corners, the splice resistance is lower. The equations above also assume that there is complete solder coverage within the splice. The equations above should be considered to be approximate in that they don't consider a number of effects such as the alloying of the solder with the copper in the superconductor and Hall effects in the splice.

\section{B. Calculation of Splice Breaking Strength}

Short splices fail in shear within the splice solder. Long splices fail in the parent material through a combination of pure tensile stress and bending stress that is induced by the distance between the conductor centers $\mathrm{t} / \mathrm{L}$. Thus short splices that are too long to fail in shear will fail at a lower tensile stress in the conductor than an infinitely long splice. The failure will occur where the bending stress is the highest (at a point right next to the splice). This kind of failure was observed in all of the $293 \mathrm{~K}$ splices that were in tension.

For short splices that fail within the splice due to shear in the solder, the tensile failure stress should be proportional to the splice length, unless bending induces brittle peeling within the splice itself. The shear failure stress for a typical soft solder at room temperature is from 20 to $35 \mathrm{MPa}$ depending on the solder and the bond quality. The length below which shear failure occurs $\mathrm{L}_{\mathrm{sf}}$ can be estimated using the following expressions;

$$
\begin{aligned}
& L_{s f} \approx \frac{\sigma_{u l t}}{\tau_{s o l}} t, \text { for up-down splices, and } \\
& L_{s f} \approx \frac{\sigma_{u l t}}{\tau_{s o l}} w, \text { for side-by-side splices, }
\end{aligned}
$$

where $\sigma_{\text {ult }}$ is the ultimate stress for the parent conductor in tension and $\tau_{\mathrm{sol}}$ is the solder shear failure stress.

For a coil conductor $\mathrm{w}=1.6 \mathrm{~mm}$ and $\mathrm{t}=0.95 \mathrm{~mm}$, the length $\mathrm{L}_{\mathrm{sf}}$, at which shear failure become dominant will be from $13 \mathrm{~mm}$ to $24 \mathrm{~mm}$ for an up-down splice. For a side-by-side splice, $\mathrm{L}_{\mathrm{sf}}$, will be from $21 \mathrm{~mm}$ to $38 \mathrm{~mm}$. The coil splice length should be long compared to $\mathrm{L}_{\mathrm{sf}}(>250 \mathrm{~mm})$.

\section{The Measurement System Set UP}

The splice resistance is calculated from the measured voltage across the splice as current is applied across the splice. The splice is wound onto a tube that can be installed into the center of a superconducting solenoid that can generate magnetic induction above $5 \mathrm{~T}$. A schematic representation of the instrumented splice is shown in Fig 2.

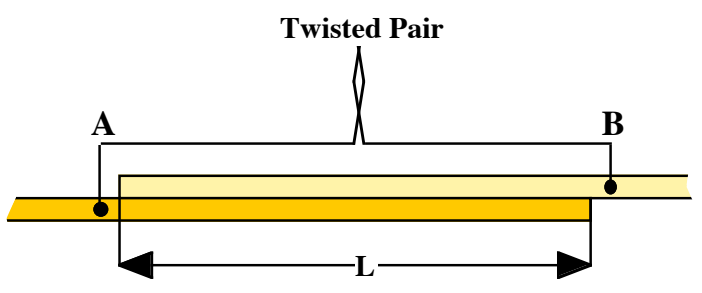

Fig. 2. A Schematic of the Voltage Taps Connected to a Splice.

The problem with measuring the splice resistance is the voltage noise generated by a number of sources. If one measures the resistance of a $0.5 \mathrm{n} \Omega$ splice using a current of $10 \mathrm{~A}$, the signal voltage across the splice will be $\sim 5 \mathrm{nV}$. This means that the noise in the experiment must be eliminated to the level lower than $5 \mathrm{nV}$. The voltage taps connected to the ends of the splice must be twisted pairs that don't couple to sources of additional voltages. Changing electric and magnetic field can induce voltages at a low level in addition to thermal voltages that can make voltage drop measurements difficult. For short splices, the signal voltages are much higher, so electronic noise is less of a factor.

The voltage measurements were made across the splice over a range of currents across the splice up to $400 \mathrm{~A}$. The voltage drop measurements were taken with the conductor current going up and going down. This technique allows one to separate the signal voltage from the noise, so that one can determine the IR voltage across the splice. This technique yields more accurate measurements than the technique used for measuring splice resistance in 2008 [3].

\section{Measurements of Splice Resistance}

The resistance of several $1000 \mathrm{~mm}$ long side-by-side and up-down hand made splices was measured in 2008 [3], [4]. These splices were made using Sn96-Ag.3.5-Cu0.5 solder (a lead free tin-silver soft solder commonly used for electronics) and $\mathrm{Sn} 63-\mathrm{Pb} 37$ solder (tin-lead eutectic solder). The measurements were done over a range of magnetic inductions up to $5 \mathrm{~T}$. The tin-silver solder splices had a resistance that was a few percent lower than the tin-lead solder splices.

The 2008 1-meter splice measurements were made for the whole splice and a $250 \mathrm{~mm}$ long section in the center of the splice. The calculated splice resistance (from the voltage drop measurements) was normalized to a 1-meter length. By normalizing the splice resistance, one had an idea of what the uniformity the conductor splice resistance. The normalized splice resistance for a $1.04 \mathrm{~m}$ splice was $1.09 \mathrm{n} \Omega$. The $250 \mathrm{~mm}$ center section had a normalized resistance is $0.88 \mathrm{n} \Omega$. This meant that the splice was of good quality. The resistance of the side-by-side splices was about a factor of 1.7 higher [4]. 
Fig. 3 shows the resistance of up-down splices as a function of their length at inductions of $0,3 \mathrm{~T}$, and $5 \mathrm{~T}$ using MICE coupling coil superconductor $(0.95 \mathrm{~mm}$ by $1.60 \mathrm{~mm})$ and Sn63-Pb37 (tin-lead eutectic) solder. The splices measured for Fig 3 were made using a jig to compress the splice so the solder thickness was reduced.

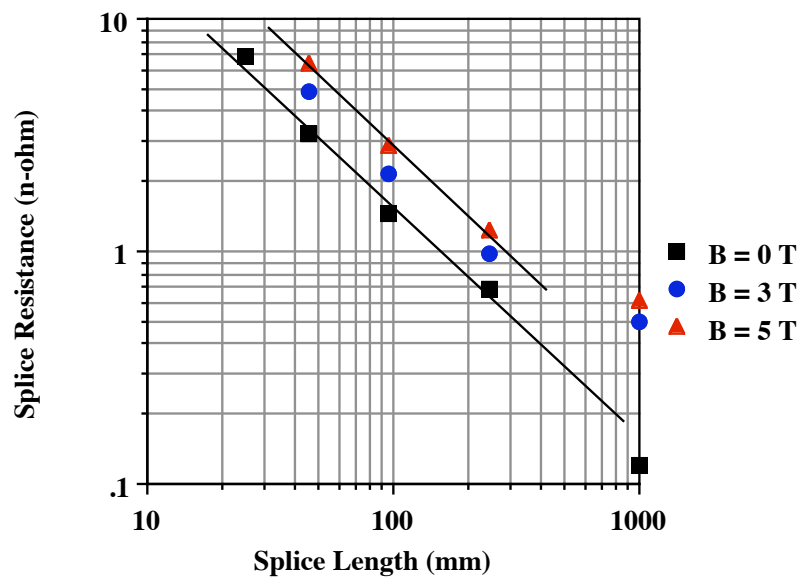

Fig. 3. The Splice Resistance as a Function of Splice Length and Magnetic Induction for Up-down Splices using 0.95 by $1.60 \mathrm{~mm}$ Bare Conductor and an $\mathrm{Sn63-Pb37}$ (tin lead eutectic solder with a melting point of $188 \mathrm{C}$ ).

From Fig. 3, it appears that the splice resistance is inversely proportional to the splice length until the splice length reaches 1-meter. The measured 1-meter long splice resistance at $\mathrm{B}=0$ appears to be inversely proportional to splice length. The 1-meter long splice resistance measurements at $3 \mathrm{~T}$ and $5 \mathrm{~T}$ appear to be too high. There has been considerable discussion as to why the 1-meter long splice resistance is different from the data for shorter splices. The differences are likely to be tied to the techniques used to eliminate noise from the splice voltage drop measurements.

It also appears that the splices made using a jig have a lower resistance than slices made my hand using hemostats as clamps. This statement may not be true, based on the measured solder thickness for both types of splices. There is not much difference in the solder thickness for the splices made using a jig. The observed differences in the measured resistance may be due to improvements in the measurement technique that was used for the jig-fabricated samples. The resistance measurement method used in 2010 appears to have a lower noise level than the method used in 2008.

\section{Measurements of Splice Breaking Strength}

A series of measurements of breaking strength were done on a number of 250-mm long splices. These measurements were done on splices with the Sn96-Ag3.5-Cu0.5 (Sn-Ag) solder and on splice samples made from Sn63-Pb37 ( $\mathrm{Sn}-\mathrm{Pb}$ eutectic) solder. Splices were broken with the splices at $293 \mathrm{~K}$ and at $77 \mathrm{~K}$. (In the case of the $77 \mathrm{~K}$ samples, the splices themselves were at $77 \mathrm{~K}$ while the conductor at the ends of the sample was at $293 \mathrm{~K}$.)

All of the $293 \mathrm{~K}$ samples broke in the conductor right next to splice, which indicates that there is a stress concentration at that location. We believe that stress concentration is caused by a bending stress in the conductor right next to the splice.
The bending stress is added to the tensile stress in the material on one side of the conductor next to the splice. We also believe that this bending stress is a function of $t / L$ where $t$ is the thickness of the conductor and $\mathrm{L}$ is the length of the splice. All of the splices that were at $77 \mathrm{~K}$ broke at the sample end near room temperature. The ultimate tensile stress for the bare conductor is much higher at $77 \mathrm{~K}$ that it is at $293 \mathrm{~K}$. None of the $250 \mathrm{~mm}$ long splices broke in the splice itself.

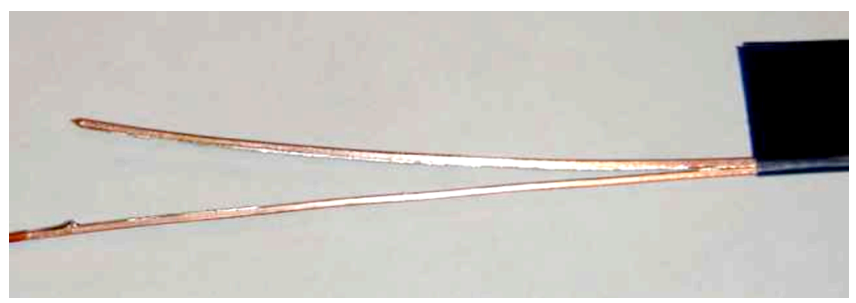

Fig. 4. Peel in a Splice made with Tin-silver Solder broken at $77 \mathrm{~K}$

The $250 \mathrm{~mm}$ long splices broken at $77 \mathrm{~K}$ exhibited peeling of one conductor in the splice from the other. The length of the peel zone varied from $10 \mathrm{~mm}$ to $120 \mathrm{~mm}$. Fig. 4 shows the peel in a splice made with $\mathrm{Sn}-\mathrm{Ag}$ solder broken at $77 \mathrm{~K}$. All of the $\mathrm{Sn}-\mathrm{Ag}$ solder samples broken at $77 \mathrm{~K}$ exhibited peel. One splice made with $\mathrm{Sn}-\mathrm{Pb}$ solder exhibited no peel at $77 \mathrm{~K}$. The other $\mathrm{Sn}-\mathrm{Pb}$ splice had a $5 \mathrm{~mm}$ long peel. We believe that the brittleness of the Sn-Ag solder at cryogenic temperature contributes to the peel exhibited in the $250 \mathrm{~mm}$ long splices measured at $77 \mathrm{~K}$.

The peel phenomena and the apparent stress concentration near the splice caused us to investigate the breaking strength of splices that were shorter than $250 \mathrm{~mm}$. Fig. 5 shows the breaking stress for soldered up-down splices of various lengths and solders. The breaking stress given in Fig. 5 is based on the parent conductor, which has a cross-section area of $1.485 \mathrm{~mm}^{2}$.

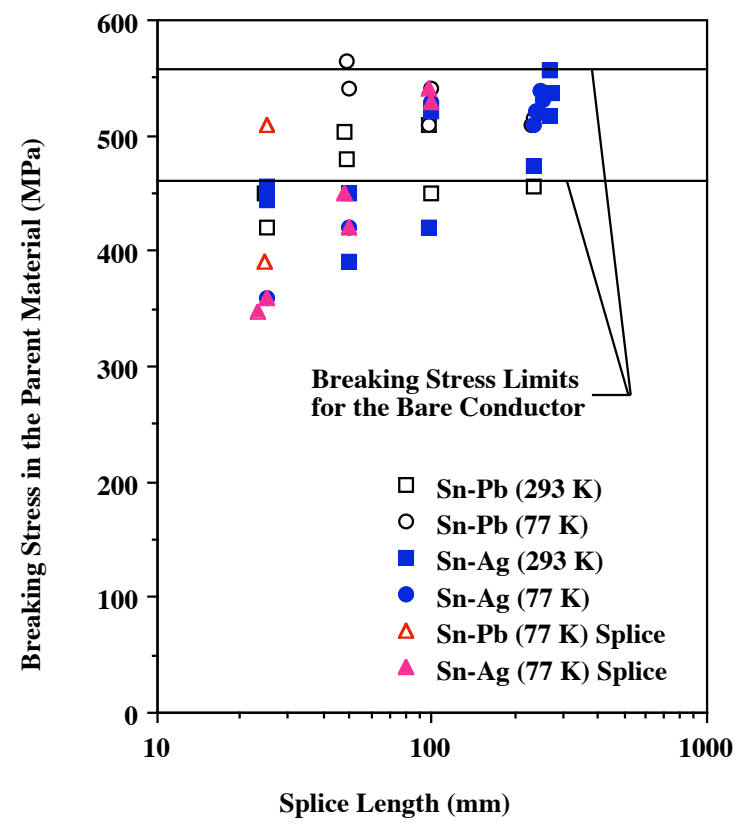

Fig. 6. The Breaking Stress of Splices of Various Lengths 
The two horizontal lines in Fig. 5 represent the upper and lower limits of the breaking stress for the bare superconductor without a splice. The breaking stress of most of the 230 to $270 \mathrm{~mm}$ splices lie within the range of the breaking stress for the conductor without a splice. The cases represented by closed and open triangles are cases where the splice broke apart during the break test. Splices made from the tin-silver solder are particularly prone to splice breakage at $77 \mathrm{~K}$. For the tin lead eutectic solders only the shortest ( $\sim 25 \mathrm{~mm}$ long) splices broke within the splice.

It is clear that the tin-silver solder is more prone to breakage than splices made with the tin-lead eutectic solder. In general, the splice breaking stress decreases as the splice get shorter. The tin-silver solder doesn't appear to be as strong as tin-lead solder, for splice lengths less than $250 \mathrm{~mm}$. In the shorter splices, there is combination of peel and shear failure within the samples. All of the tin-silver solder splices peeled when they broke at $77 \mathrm{~K}$. The tin-lead eutectic splices were far less far less likely to peel. Fig. 6 shows a hand made tin-silver solder splice that had been stressed, but hadn't failed within the splice. One can see that the solder in the splice is cracked.

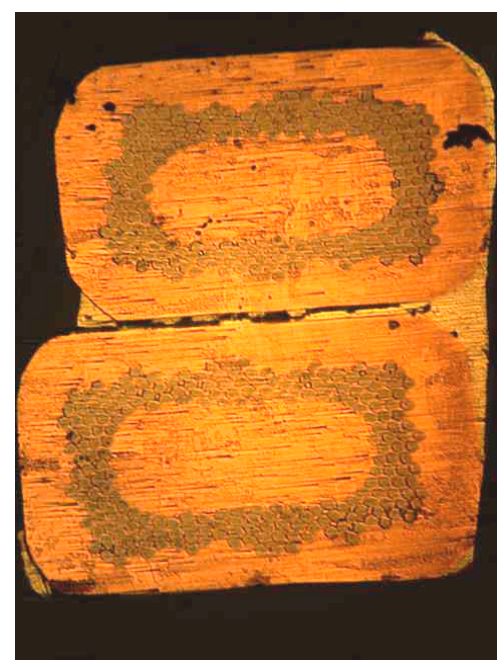

Fig. 6. A cross-section of a Cracked Sn-Ag Up-down Splice (Note the solder thickness in the splice before the spice crack appears to be less than $50 \mu \mathrm{m}$.)

\section{CONCLUSIONS.}

There are a number of conclusions that can be drawn from the splice measurements that have been made to date. From the measurements we find the following: 1) The splice length should be at least ten times the length at which the splice will fail due to shear failure in the solder. We believe that longer splices also reduce the effects of bending stress in the conductor. 2) Splices must be mechanically supported. Do not depend on the solder in order to keep the splice from coming apart. 3) The tin-silver solders (favored by those who want to get the lead out of solder) should be avoided. Tin-silver solders commonly used for room temperature electronics are very brittle at temperatures less than $150 \mathrm{~K}$ [10]. Pure tin as a solder should also be avoided, because of a low temperature phase change that occurs in tin. The low temperature properties of lead-free solders must be well understood before the solders are used.

In addition the authors of this paper make the following general recommendations concerning splices: 1) The melting point of the highest melting point solder in the splice must be less than the temperature that spoils the heat treatment of the superconductor (for $\mathrm{Nb}-\mathrm{Ti}$, this is $<250 \mathrm{C}$ ). 2) Splices made with two solder joints must have solders with different melting point temperatures in the joints. The part of the splice made first (usually between two superconductors) must be soldered together using the higher melting point solder (a solder with more lead). The second part of the splice (usually copper around a conductor) should be soldered using a lower melting point solder (such as tin-lead eutectic). In this instance careful temperature control is needed to keep the higher temperature solder splices from melting while the lower temperature parts of the splice are being fabricated. 3) Splices should be inspected before they are sealed into a coil or a magnet cryostat. This means that inspection criteria must be developed and implemented.

\section{REFERENCES}

[1] C. A. Baldan, U. R. Oliveira, C. Y. Shigue, and E. R. Filho, "Evaluation of Electrical Properties of Lap Joints for BSCCO and YBCO Tapes," IEEE Transactions on Applied Superconductivity 19, No. 3, p 2831, (2009).

[2] G. Gregoire, G. Ryckewaert, L. Chevalier, et al, "MICE and International Muon Ionization Experiment Technical Reference Document," http://www.mice.iit.edu, 2001.

[3] M. A. Green, D. Dieterich, H.C. Higley, et al, "The Calculated and Measured Resistance for Splices between Conductors in a MICE Superconducting Coil," MICE Note 238, http://www.mice.iit.edu.

[4] F. Y. Xu, H. Pan, H. Wu, et al, "Measurement of Resistance and Strength of Conductor Splices in the MICE Coupling Magnets," to be published in Advances in Cryogenic Engineering 55, AIP Press, Melville NY (2010).

[5] L. Wang, F. Y. Xu, H. Wu, et al, "Magnetic and Cryogenic Design of the MICE Coupling Solenoid Magnet System," IEEE Transactions on Applied Superconductivity 19, No. 3, p 1344 (2009), MICE Note 234, http://www.mice.iit.edu.

[6] D. E. Baynham, T. W. Bradshaw, J. H. Cobb, et al, "Progress on the Design and Fabrication of the MICE Focusing Magnets," to be published in IEEE Transactions on Applied Superconductivity 20, No. 3, (this publication) (2010).

[7] X. L. Gou, Harbin Institute of Technology, private communication concerning the $25-\mathrm{nW}$ resistance of $6-\mathrm{mm} 2$ cross-section area butt splice.

[8] Handbook of Materials for Superconducting Machinery, Metal and Ceramics Information Center, MIC-MB-04, National Bureau of Standards, January 1977.

[9] F. Heringhaus and T. A. Painter, "Magnetoresistance of Selected Sn and $\mathrm{Pb}$ based solders at $4.2 \mathrm{~K}$," Materials Letters 57, Issue 4, pp 787-793, Elsevier BV (2002).

[10] Phil Eckels General Electric (retired) private communication concerning the fracture toughness data for tin-silver solders at low temperature. 